\title{
Maaseutuyrittäjät viherympäristöpalveluiden tuottajina
}

\author{
Petri Kapuinen ${ }^{1)}$, Hannele Partanen ${ }^{2)}$, Seppo Pentti ${ }^{3)}$ ja Matts Nysand ${ }^{4)}$ \\ ${ }^{1)}$ Maa- ja elintarviketalouden tutkimuskeskus, Ympäristötutkimus, Maaperä ja ympäristö, 31600 Jokioi- \\ nen, petri.kapuinen@mtt.fi \\ ${ }^{2)}$ Maa- ja kotitalousnaisten Keskus, PL 251,01301 Vantaa, hannele.partanen@proagria.fi \\ ${ }^{3)}$ Työtehoseura ry., Maatalousosasto, PL 13, 05210 Rajamäki, seppo.pentti@tts.fi \\ ${ }^{4)}$ Maa- ja elintarviketalouden tutkimuskeskus, Maatalousteknologian tutkimus, Vakolantie 55, $03400 \mathrm{VIH}$ - \\ TI, matts.nysand@mtt.fi
}

\section{Tiivistelmä}

Kuntien viherympäristönhoidossa pyritään ulkoistamiseen ja seutukunnallistamiseen sekä tilaaja-tuottaja malliin kustannuspaineiden ja henkilöstön nopean eläköitymisen takia. Viljelijät osallistuvat hoitoon vuokraamalla kunnilta peltoa tuottaen maisemapeltoa vastaavaa ympäristöelementtiä sekä urakoitsijoina tehtävissä, joissa vaaditaan nimenomaisesti maanviljelytaitoa ja sitä vastaavaa koneistusta. Näissä tehtävissä viljelijöiden käytön osuus ei edes juuri voisi enää nousta lukuun ottamatta niittymäisesti hoidettavien alueiden eli maisemaniittyjen hoitoa samantapaisena toimintamuotona kuin maisemapeltojenkin hoidossa.

Maatiloilla olisi kalustoa myös muihin tehtäviin, mutta he joutuvat kilpailemaan niissä samoista lähtökohdista muiden urakoitsijoiden kanssa. Tällöin ammattitaito nimenomaisesti urakoitsijana nousee hallitsevaksi. Yli puolet kunnista oli käyttänyt ja lähes neljännes oli halukas jopa lisäämään viljelijöiden käyttöä urakoitsijoina, mutta sitä rajoittaa ilmeisesti sopivien tehtävien ja määrärahojen määrä. Seurakunnat käyttävät viljelijöitä tarpeelliseksi ja tarkoituksenmukaiseksi katsomassaan laajuudessa ja nimenomaisesti peltojen viljelyssä. Niiden näkemykset olivat varsin selviä ja oman työn käytön osuus oli suuri sekä rahanpuute kuntienkin rahapulaa suurempi. Määrärahat tuskin ovat merkittävästi lisääntymässä, vaikka niistä on eniten puutetta. Seuraavaksi eniten on pula vihertoimesta vastaavien ajasta ja sitten suorittavasta työvoimasta. Haluja ottaa uusia alueita hoidon piiriin kuitenkin on.

Suurin osa kuntien avoimista alueista on näkyvillä paikoilla. Hoitamattomat alueet painottuvat vähemmän näkyvillä paikoilla, mutta niitä on runsaasti myös näkyvillä paikoilla. Resurssien puute näkyy pusikoituvina peltoina. Hoidettavien alueiden laajentaminen samalla rahalla on mahdollista siirtämällä alueita A-hoito- ja käyttöluokista edullisimpiin maaseutumaisesti hoidettaviin B-hoito- ja käyttöluokkiin, joita yleisö arvostaa ainakin kohtuullisena osuutena yhtä korkealle kuin rakennettua viherympäristöä. Kuntissa on kuitenkin selvää epävarmuutta asukkaiden toiveista, minkä takia lähes puolessa kunnista epäröidään muuttaa rakennettua viherympäristöä maaseutumaisesti hoidettavaksi. Asiaan voitaisiin vaikuttaa heidän kouluttamisellaan ja tutkimuksilla, joissa asukkaiden mieltymyksiä selvitettäisiin ja tietoisuutta niistä lisättäisiin. Muutos lisäisi viljelijöille sopivien hoitokohteiden osuutta ja määrää.

Parhaiten viherympäristönhoitotöihin olisi aikaa kasvinviljelytiloilla, joiden kalusto sopii parhaiten maisemapellon viljelyyn, viheralueiden peruskunnostukseen ja maisemaniittyjen niittoon. Kerättäessä niittojäte tarvitaan tyypillistä nautakarjaeläintilan kalustoa, jota saattaa olla kasvinviljelytilalla karjatalousajalta.

Maataloustyökoneet saattavat olla liian isoja ja raskaista joihinkin viherympäristönhoitotöihin paikkojen ahtauden tai maan märkyyden takia, mutta liian keveitä joihinkin maansiirtotöihin tai rakenteellisesti liian heikkoja kestämään yleisillä viheralueilla usein esiintyviä vierasesineitä. Varsinkin vierasesineistä vapaa viheralueilta poistettu biomassa voidaan hyödyntää maatilalla eri tarkoituksiin. Maatilojen koneiden hyödyntämättömyys saattaa johtua myös pelkästään siitä, että maatilojen koneiden soveltuvuutta ei vain tunneta viheralan ammattilaisten keskuudessa. Pitkät sopimukset mahdollistaisivat suunnitelmalliset investoinnit, joissa voidaan ottaa huomioon myös sen soveltuvuus viherympäristönhoitourakointiin, jotka saattavat avata mahdollisuuden edullisiin rahoitusvaihtoehtoihin.

Asiasanat: viherympäristön hoito, ulkoistaminen, seutukunnallistaminen, tilaaja-tuottaja -malli, maisemapelto, maisemaniitty, urakointi, viljelijä, maaseutuyrittäjä, maaseutuyritys, kunta, seurakunta, vihertoimi, maatalouskone 


\section{Johdanto}

\section{Maaseutumaiset alueet taajamassa}

Maaseutumaisten alueiden, kuten peltojen ja niittyjen, arvostus hoidettuina viheralueina on kasvamassa erityisesti suuremmissa kaupungeissa, mutta myös maalaiskunnissa. Näitä alueita voidaan käyttää virkistykseen, ja ne toimivat kuntien käyntikortteina. Avoimien kulttuurimaisemien säilymistä ja hoitoa myös taajamien läheisyydessä pidetään valtakunnallisesti tärkeänä asiana, ja ne ovat osa valtakunnallisia alueidenkäyttötavoitteita (YM 2003). Uusittua maaseutumaisten alueiden B-hoitoluokitusta voidaan tulevaisuudessa käyttää yhtenä kaavoittajan työvälineenä, ja se on yksi viheralan tärkeimmistä työkaluista. Niiden avulla yhtenäistetään viheralueiden käsitteistöä sekä tehdään kunnissa päätöksiä alueiden hoidosta ja hyväksyttävistä kustannuksista. Maaseutumaisten alueiden luokitusta (Viherympäristöliitto 2000) halutaan laajentaa, koska se on liian suppea alueiden hoidon ja käytön kehittämiseksi. Aikaisempien luokkien: B1 (maisemapellot) ja B2 (maisemaniityt) lisäksi on esitetty luokkia: B3 (käyttöniityt), B4 (arvoniityt), B5 (laidunalueet) ja B6 (avoimet alueet ja näkymät) (Partanen ym. 2004).

Nykyisessä tiiviissä kaupunkirakenteessa niitty- ja peltoalueiden käytön tavoitteet voivat olla erilaiset kuin perinteisessä viljely- ja laidunkäytössä. Hoidon tavoitteena on yleensä monimuotoisuus ja vaihteleva maisemakuva sekä maiseman avoimena säilyminen eikä toimeentulon hankkiminen, kuten ennen.

Maaseutuyrittäjät voivat hoitaa taajamissa useita erityyppisiä maaseutumaisia alueita, kuten taajamien reuna-alueita ja sisääntuloja, umpeen kasvaneita peltoja ja näkymiä, maisemapeltoja, viljelyssä olevia peltoja, niittymäisiä alueita, perinnemaisemia, ranta-alueita, kaavoitusta ja rakentamista odottavia alueita, rakentamattomia viheralueita, liikenteen välialueita ja levähdysalueita sekä voimalinja- ja sähkölinjaalueita.

Taajamien niityt voidaan maisemaniittyinä hoitaa helpommin ja pienemmillä kustannuksilla kuin nurmikot samalla edistäen luonnon monimuotoisuutta. Rakennetun viheralueen hoitokustannukset A2 ja A3-alueella ovat $1,04 \mathrm{ja} 0,47 € \mathrm{~m}^{-2} \mathrm{a}^{-1}$ (Partanen ym. 2004). Vastaavasti B2-alueen hoitokustannus on vain $0,051 € \mathrm{~m}^{-2} \mathrm{a}^{-1}$. Hoidon kustannukset A-alueella ovat siten $10-20$-kertaiset B-alueen hoidon kustannuksiin nähden. B-alueiden hoidon kustannukset ovat jopa pienemmät kuin taajametsien $0,15 € \mathrm{~m}^{-2} \mathrm{a}^{-1}$. Ihmiset kuitenkin arvostavat myös maaseutumaiset alueet varsin korkealle. Esimerkiksi Marketanpuistossa kesällä 2004 järjestetyssä kyselyssä 81 \% vastaajista arvosti luonnonniittyä ja vain 19 \% rakennettua puistoa. Kevytliikenteen väylien pientareiden tila on tärkeä luonnolle ja luonnossa kulkeville. Peltojen ja metsien reunavyöhykkeet sekä ranta-alueet ovat maisemallisesti ja virkistyskäytön kannalta monipuolisia alueita. Maisemapellot ovat viimevuosina olleet ratkaisuna taajamien läheisyydessä viljelystä pois jääneiden peltojen välikäyttönä. Ne tarjoavat ohikulkijoille mielenkiintoista seurattavaa. Taajamien asukkaat arvostavat hoidettuja vaihtelevia metsiä ja maaseutumaisia alueita, koska he pitävät niitä turvallisempina kuin hoitamattomia. Jotta avoimet alueet saataisiin mahdollisimman hyvin hoidon piiriin, niiden tulee kuitenkin olla esillä kaikissa viheralueisiin liittyvissä suunnitelmissa, kaavoituksesta viheralueohjelmiin ja alueiden hoitosuunnitelmiin. Ne jo sinänsä lisäävät alueiden arvostusta.

\section{Maisemanhoidosta yritystoimintaa}

Ympäristötöihin katsotaan yleensä kuuluvan esimerkiksi viherympäristön hoito, kunnostus ja ylläpito, lumityö, laskeutusaltaiden rakentaminen ja kunnostus, jätehuolto, puhtaanapito, liikuntapaikkojen hoito sekä metsänraivaus. Viherympäristötöitä ovat esimerkiksi niitto, kastelu ja lannoitus. Urakoitsijoiden tekemänä näitä kutsutaan ympäristö- tai viherurakoinniksi taikka -palveluksi.

Maatalous- ja maaseutupolitiikassa suositaan monipuolisia maatiloja, jotka harjoittavat esimerkiksi maaseutuyritystoimintaa, kuten maatilamatkailua, koneurakointia ja elintarvikkeiden jatkojalostusta. Nykyisin on tavallista, että tilat ulkoistavat esimerkiksi kasvinsuojeluruiskutuksia ja rehuntekoa. Vastaavasti kunnat voivat ulkoistaa maiseman-, luonnon- ja ympäristönhoitoa. Viljelijä voi hankkia tehokkaat koneet, joiden avulla hän voi hoitaa muiden viljelijöiden sekä kuntien ja muiden lähistön maanomistajien hoidon tarpeessa olevat alueet. Tässä viljelijä voi hyödyntää erityisympäristötukialueidensa hoidossa saatua ammattitaitoa ja kokemusta. Lisäksi yritysmäinen toiminta lisää työn arvostusta.

Maisemanhoitoon ammattimaisesti suuntautuneet ovat usein toimineet pitkään maa- ja metsätalouden ammateissa ja ovat kiinnostuneet laajentamaan ammattiosaamistaan. Heille maisemanhoito tarjoaa uuden lisäansiomahdollisuuden. Osa on kiinnostunut alan yrittäjyydestä, ja suurimmalla osalla heistä on jo yrittäjäkokemusta. Kummassakin roolissa toimiville tulevaisuus tarjoaa runsaasti töitä. Viherympäristön- 
hoitourakointia, joka keskittyy kasvukauden aikaan, voi olla kuitenkin vaikea sovittaa eteenkin karjatilan normaalien viljelytoimien, säilörehun- ja heinänkorjuun ja lannanlevityksen, lomaan, mutta kasvinviljelytilille ne sopivat paremmin niiden omien sesonkien lyhyyden takia (Klemola ym. 2000). Kasvinviljelytiloilla on myös enemmän potentiaalista vapaata työaikaa käytettävissä urakointiin. Urakointitoiminnan sopivuuden kannalta maaseutuyrittäjälle on oleellista työn toteutusajankohta ja mahdollisuus tarjota asiakkaille sopivia kokonaisuuksia sekä kulkuetäisyydet taajamien hoitokohteisiin. Maisemapeltojen ja niittyjen hoitotöillä ei ole kiinteää aikaa, vaan ne ajoittuvat asiakkaan toiveiden mukaisesti, mutta ne ovat yleensä sopineet kasvinviljelytilan töiden lomaan. Viherympäristönhoitourakoinnin aloittaminen edellyttää ainakin yrittäjämäistä suhtautumista ja kohtalaisia taitoja vihertöissä ja ymmärrystä vihertöistä. Yleensä yrittäminen aloitetaan vähitellen ja kokemuksen karttuessa toimintaa laajennetaan niin, että sen osuus tilan liikevaihdosta muodostaa lopulta kohtuullisen osuuden. Jotta kuntien asettamat tavoitteet voidaan täyttää, viherympäristönhoitourakoinnin pitää käytännössä olla maaseutuyrittäjälle toinen ammatti. Viherympäristönhoitourakoitsijaksi päätymiseen tyypillisiä vaihtoehtoja on:

1) Tilaaja kääntyy tarjouspyynnön kanssa potentiaalisen urakoitsijan puoleen ja tämä vastaa siihen,

2) Yrittäjä kiinnostuu urakoinnista ja jättää tarjoukseen yleisen tarjouspyynnön perusteella,

3) Tämä aloittaa esimerkiksi kunnan työntekijänä ja päätyy urakoitsijana hoitamaan samoja tehtäviä tai

4) Tämä aloittaa urakoitsijan työntekijänä ja jatkaa itsenäisenä urakoitsijana.

\section{Viherympäristön hoidon ulkoistaminen}

Monet kunnat vähentävät omaa viheralueita hoitavaa työvoimaansa sen lisäksi, että se on eläköitymässä nopeaan tahtiin, saavuttaakseen kustannussäästöjä ja antavat tehtävien hoidon urakoitsijoille. Erityisesti sesonkiluonteisia töitä teetetään urakoitsijoilla. Ensimmäisenä kustannuksia ollaan karsimassa usein teknisen toimen osana olevasta vihertoimesta. Kunnat etsivät aktiivisesti uusia muotoja hoitaa viheralueiden hoito. Suurimmissa kunnissa yleistyy tuottaja-tilaajamalli, jossa tilaajan on kunnan vihertoimi ja tuottajana on kunnan oma viherympäristöpalveluiden tuotanto tai ulkopuolinen yrittäjä. Paineita ulkoistamiseen lisää se, että kolmannes kuntien henkilöstöstä on siirtymässä eläkkeelle vuoteen 2010 mennessä. Kunnat yrittävät lievittää resurssien niukkuutta myös seutukuntayhteistyön avulla, jossa tehtävät voidaan mitoittaa urakoitsijalle sopivan kokoisiksi.

\section{Aineisto ja menetelmät}

Kuntien vihertoimesta vastaavien näkemyksiä viherympäristön hoidon kehittämisestä selvitettiin kirjekyselyn avulla. Kyselylomake lähetettiin kaikille kunnille. Kyselyyn vastasi 88 kuntaa, joista 37 oli kaupunkeja. Kyselyyn vastanneet kunnat painottuivat maan länsiosaan Vaasa-Lappeenranta -linjan lounaispuolelle. Vastanneet kaupungit ja kunnat jakaantuivat maantieteellisesti yhtäläisesti. Kaupunkien vastausprosentti oli korkeampi, 33,3\%, kuin maalaiskuntien, 15,2\%. Oletettavasti maalaiskuntien motivoituminen vastaamaan kyselyyn oli pienempi, koska niissä kuntien omistamien maaseutumaisten alueiden määrä on pienempi. Vastausten täydellisyys vaihteli suuresti. Seurakuntien vastausprosentti ja -määrä oli pieni. Tämä saattoi näkyä vastaajien valikoitumisena.

Kirjekyselyn perusteella ja joidenkin kuntien muuten tiedetyn merkityksellisyyden perusteella asiassa valittiin kuntia haastattelututkimukseen niiden vihertoimen toiminnan tarkemmaksi selvittämiseksi. Yhdeksän kunnan vihertoimeen osallistuvien 15 haastatellun henkilön lisäksi haastateltiin yhtä konsulttia ja yhtä kirkkohallituksen edustajaa. Vastaavasti näille kunnille palveluita tuottavia urakoitsijaa haastateltiin kuusi. Samassa yhteydessä kerättiin tietoa kuntien vihertoimen ja urakoitsijoiden koneistuksesta käsittäen käytettävät koneet sinänsä mutta myös toimijoiden kokemuksista yksittäisten konetyyppien käytöstä.

\section{Tulokset ja tulosten tarkastelu}

\section{Kuntien vihertoimi ja hoidettavat alueet}

Yli puolella vastanneista kunnista, 55 \%:lla oli itsenäinen vihertoimi. Muissa kunnissa sitä harjoitettiin osan muuta tointa, oletettavasti teknistä tointa. Seurakunnissa oma itsenäinen vihertoimi oli peräti 94 \%:lla. Suurin ongelma maaseutumaisten alueiden hoidossa oli rahan puute, toiseksi suurin vihertoimesta vastaavien ajanpuute ja kolmanneksi pula suorittavan portaan työpanoksesta. Sen sijaan koneiden puutetta ei pidetty kovin merkittävänä ongelmana. Vain $9 \%$ vastanneista kunnista koki konepulaa. 
Vastanneista kunnista 59 - 72 \%:lla oli avoimina maaseutumaisina alueina vuokralle annettuja viljeltyjä peltoja, niittymäisesti hoidettavia peltoalueita, hoitamattomia pusikoituvia peltoja sekä niittyjä, ketoja tai hakamaita. Vain neljänneksellä kunnista oli omaan lukuun viljeltäviä peltoja, ja viljeltävä ala

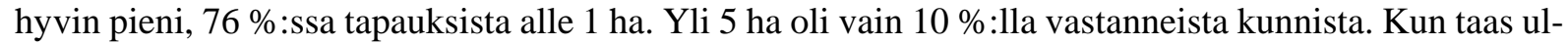
kopuolisille vuokrattuja peltoja oli 68 \%:lla vastanneista kunnista, ja se oli sitä yleisempää, mitä suurempi kunnan omistama peltopinta-ala oli. Ilmeisesti pienet peltoalat olivat jääneet kunnille käsiin. Joillakin suurilla kaupungeilla, kuten Helsingillä ja Vantaalla, on merkittävää omaan lukuun harjoitettavaa maataloutta. Seurakunnat viljelivät harvoin peltojaan itse, ja jos viljelivät, pinta-ala oli alle 1 ha.

Kunnat teettävät pääsääntöisesti, 84 \% vastanneista, myös omaan lukuun viljelyynkin liittyvän viljelyn viljelijöillä. Virallisia maisemapeltoja eli B1-alueita ovat vain kuntien omassa hoidossa olevat alueet, mutta epäviralliset maisemapellot mukaan lukien hoito on jo varsin pitkälle ulkoistettu teettämällä viljelytyöt viljelijöillä ja muilla urakoitsijoilla tai vuokraamalla pellot viljelijöille. Seurakunnat käyttävät peltojen viljelyn vain ja ainoastaan viljelijöitä.

Niittymäisesti hoidettuja peltoalueita eli käytännössä maisemaniittyjä eli B2-alueita oli 67 \%:lla vastanneista kunnista, yhtä monella kuin ulkopuolisille vuokrattuja peltoja. Niitä kunnilla on yleensä alle 50 ha, tyypillisesti $1-5$ ha. Niittymäisten alueiden hoito jakaantuu selvästi tasaisemmin kuin varsinaiset viljelytyöt kunnan oman työn, viljelijäurakoitsijoiden ja muiden urakoitsijoiden kesken. Merkittävimpänä tekijänä lienee se, että viljelytöihin tarvitaan huomattavasti monipuolisempaa maatalouskonekantaa ja viljelyn ammattitaitoa kuin pelkkään niittoon, mikä vähentää viljelyurakoitsijoiden kilpailukykyä niittotöissä. Muissa viherympäristötöissä kuin varsinaisissa viljelytöissä ja niittyjen hoidossa kuntien viljelijöiden käytön osuus urakoitsijana on varsin pieni. Harvemmalla seurakunnalla kuin kunnalla on niittymäisiä alueita, ja ne ovat pienempiä. Seurakunnat tyypillisesti hoitivat nämä alueet omin voimin.

Hoitamattomia pusikoituvia peltoja on peräti 72 \%:lla kunnista, yleensä alle 50 ha, mutta yleisimmin $1-5$ ha. Peltojen pusikoituminen näyttää olevan varsin yleistä. Osa pelloista hoidetaan, mutta osa jää pusikoitumaan rahojen ja muiden resurssien puutteen takia. Harvemmilla seurakunnilla kuin kunnilla oli pusikoituvia peltoja, mutta jos niitä oli, niiden pinta-ala on yhtä suuri kuin kunnissa. Jos peltojen hoitoon olisi varoja, avautuisi viljelijöille huomattava tehtäväkenttä. Pusikoitumisen jälkeen palauttaminen viljelyyn tai niittymäiseen käyttöön vaatii jo järeämpää kalustoa, mitä viljelijöillä yleisesti on.

Niittyjä, ketoja ja hakamaita oli vastanneista kunnista 59 \%:lla ja yleisimmin alle 1 ha, mutta yleisesti alle 50 ha. Niitä oli yhtä suurella osuudella seurakunnista, mutta niiden pinta-ala oli jonkin verran pienempi kuin kunnissa. Teiden varsia kunnat hoitivat keskimäärin 79 kilometrin matkalla, mutta kyselyssä jäi hieman epäselväksi, tarkoittivatko kunnat tällä tien molempien piennarten hoitoa yhteen vai erikseen laskien.

Kuntien avoimista alueista vähintään 20 \% oli yleisesti näkyvällä paikalla. Yleisimmin näkyvällä paikalla oli $60-80 \%$ avoimista alueista. Avoimien alueiden näkyvyyden takia niiden hoidon lisääminen siistisi huomattavasti yleisön näkemiä alueita ja kuntien imagoa sekä parantaisi alueiden viihtyvyyttä. 95 $\%$ :ssa kunnista vihertoimesta vastaavat pitivätkin maaseutumaisten alueiden hoitoa niiden virkistyskäytön ja viihtyvyyden kannalta vähintäänkin tärkeänä, puolet jopa erittäin tärkeänä. Seurakuntien avoimista alueista selvästi suurempi osuus kuin kuntien on näkyvällä tai keskeisellä paikalla.

\section{Maaseutumaisesti hoidettavien alueiden lisäämishalukkuus}

34 \% kunnista oli kiinnostunut lisäämään hoidon piirissä olevia maaseutumaisia alueita 45 \%:n harkitessa sitä, jos se voitaisiin toteuttaa kohtuullisin kustannuksin. Vain $20 \%$ ei halunnut lisätä niitä. Tämän lisäksi $34 \%$ kunnista kiinnosti siirtää puistomaisesti hoidettavia A-alueita maaseutumaisen hoidon piiriin eli Balueiksi, ja 41 \% harkitsi sitä. Kuitenkin 18 \% ei tätä harkinnut. Merkittävä 7 \%:n osuus ei ollut muodostanut kantaansa. Seurakunnissa mielipiteet asiassa olivat selvät. Yhtä suuri osa seurakunnista kuin kunnistakin oli kiinnostunut maaseutumaisen hoidon osuuden lisäämisestä, mutta epäröiviä ei juuri ollut.

\section{Viljelijöiden käyttö viherympäristönhoitourakoinnissa}

Kunnat pitivät pystyvien urakoitsijoiden puutetta merkittävänä ongelman. Vain 31 \% katsoi, että heitä on tarpeeksi. Epätietoisten osuus, 15 \%, oli kuitenkin huomattava, mikä viittaa siihen, että urakoitsijoiden ammattitaitoa ei tunnettu riittävästi tai heidän käyttöään ei oltu edes kokeiltu. Viljelijöiden käyttö urakoitsijoina oli kuitenkin varsin yleistä. 59 \% vastanneista kunnista oli jo käyttänyt heitä ja näiden lisäksi $23 \%$ oli valmiita lisäämään viljelijöiden käyttöä. Lisäksi 16 \% kunnista oltiin valmiita ainakin kokeilemaan viljelijöiden käyttöä urakoitsijana. Vain 2 \% kunnista ei ollut kiinnostunut. Vaikutti myös siltä, että viljeli- 
jöiden toivottiin olevan aktiivisempia palveluidensa tarjoajina. Viljelijöiden passiivisuus palveluiden tarjoajana saattoi vähentää heidän osuuttaan muissa kuin heille parhaiten sopivissa tehtävissä eli varsinaisissa viljelytöissä. Seurakunnat olivat haluttomia käyttämään viljelijöitä urakoitsijoina, mutta ne seurakunnat, jotka katsoivat, että heidän alueellaan on pystyviä viherympäristönhoitourakoitsijoita, saattoivat käyttää myös viljelijöitä urakoitsijoina.

\section{Maaseutuyrittäjien kokemukset kunnista palveluiden hankkijoina}

Maaseutuyrittäjien toiminta urakoitsijoina perustuu pääosin omaan ja perheen työpanokseen. He kokivat tekevänsä työtehtävät asiakkaiden toivomalla tavalla ja asiakkaan eli kunnan luottamuksen lisääntyneen vuosien varrella. Yrittäjät pitivät kuntia samanlaisina sopimuskumppaneina kuin mitä muuta tahoa tahansa. Kunnat odottavat urakoitsijoiden tekevän työt sopimusten mukaan, laatutasovaatimuksella on taipumus kohota korvauksen kohoamatta. Varsinkin alussa laatutasosta pitää olla selkeät ohjeet, mutta kokemuksen karttuessa osalle urakoitsijoista muodostuu käsitys ilman mittareita ja ohjeitakin siitä laatutasosta, jolla toimitaan. Yksiselitteisten kaikkien osapuolten tiedossa olevien mittareiden avulla toiminta on kuitenkin molemmille osapuolille selkeää ja ongelmatonta.

Lisätöistä sovitaan tarpeen mukaan ja niitä teetetään tarkoituksenmukaisesti. Urakoitsijoita myös kuultiin päätöksenteossa asiantuntijoina töiden tarkoituksen mukaisuudesta. Urakoitsijan tulisi myös ymmärtää sanoa mielipiteensä, jos teetettäväksi aiotun työn jälki tai kustannukset eivät olisi asiakkaan odottamia. Myös urakoitsijat odottavat saavansa palautetta hoidon laadusta.

\section{Tarjouspyyntö, urakkatarjous ja sopimus}

Tarve sopimusten tekoon on viljelijäurakoitsijalla yhtä suuri kuin millä tahansa urakointiyrittäjällä. Resurssien suunnittelun tarve, tarve töiden ajoitukseen ja organisointiin, on sitä suurempi, mitä päätoimisemmaksi urakointi muuttuu. Tämä on tärkeää, jotta työtehtävät voidaan ketjuttaa turhia odotuksia välttäen. Sopimusten tekoon saattaa kuitenkin liittyä käsitteellisiä ongelmia. Viljelijät ja viheralan ammattilaiset saattavat ymmärtää samat käsitteet eri tavoin, jolloin työtä ei tehdä yhteisesti sovittujen pelisääntöjen mukaan. Tästä syystä sopimuksissa on oltava tavallista enemmän esimerkkitapauksia, niiden tulee olla yleistajuisia ja tilaajan on ehkä panostettava enemmän sopimusten tekoon kuin viherympäristön hoidon ammattilaisten kanssa. Viljelijät osaavat suvereenisti viljelytyöt, mutta esimerkiksi niiton ajoitus saattaa monimuotoisuuden tai jonkin muuna vastaavan syyn takia olla viljelijälle outo.

Urakkatarjousten pyytämistä ja käsittelyä ohjaavat säännökset julkisista hankinnoista. Tilaaja ilmoittaa tarjouspyynnössä yksityiskohdat, jotka halutaan tarjouksessa selvitettävän. Jos urakoitsija ei ole varma jonkin yksityiskohdan tarpeesta tarjouksessa, se kannattaa siihen kirjata, koska tarjouksen käsittelijä ei voi arvata esimerkiksi urakoitsijan ammattitaitoa ja kaluston sopivuutta tehtävään. Urakkatarjous voidaan haluta hoitosopimuksesta tai yksittäisistä työvaiheista. Hoitosopimusmuotoinen toiminta edellyttää urakoitsijalta vankkaa ammattitaitoa urakoitsijana. Ne ovat kuitenkin urakoitsijan kannalta parempia, koska silloin hän voi paremmin vaikuttaa työn toteuttamiseen. Yksittäisten työvaiheiden ostaminen puolestaan vaatii tilaajalta enemmän työsuoritusten seurantaa ja suunnittelua, mutta on urakoitsijalle helpompi toimintamuoto. Pitkäaikaiset hoitosopimukset kuitenkin jäntevöittävät tilaajan ja urakoitsijan resurssien suunnittelua. Pitkäaikaiset sopimukset tekevät mahdolliseksi suunnitelmallisen kaluston ja työvoiman hankinnan sekä tehtävän oppimisen ja yrittäjäverkkojen luomisen.

Tilaaja pyrkii tarjouspyyntönsä muotoilussa itsensä kannalta kokonaistaloudelliseen tavoitteeseen. Tilaajan valvontaresurssien ollessa niukka työsuorituksen toteutumista ja laatua tarkastellaan jo tarjouspyynnössä lopputuloksen perusteella. Tässä tilanteessa viljelijäurakoitsijoiden kannattaa tarjota urakkaa ryppäänä tai jonkun muun pääurakoitsijan aliurakoitsijana. Työvaiheet on kuitenkin tarjouksessa yksilöitävä niin, että käsittelijälle ei jää mikään oleellinen asia epäselväksi. Viherympäristönhoitourakoissa käytetään urakkamuotoina ainakin yksikköhintaurakkaa, kokonaishintaurakkaa, kuntovastuu-urakkaa ja jaettua urakkaa (Eskola 2003). Yksikköhintaurakassa työsuorituksille on yksikköhinta esimerkiksi €/kpl. Kokonaishintaurakat ovat suuria. Kokonaisuuden kattavan hinnan lisäksi tilaaja yleensä pyytää yksikköhinnat tilaukseen sisältymättömistä lisä- ja muutostöistä. Kuntovastuu-urakassa urakoitsijan vastuu ulottuu takuuaikaan ja sen jälkeisiin ylläpitotehtäviin. Muoto sopii esimerkiksi viheralueen kunnostukseen ja sitä seuraavaan hoitoon. Jaettu urakka on jaettu tarkoituksenmukaisiin osiin. Työn tilaaja ja seuraavan osan urakoitsija hyväksyvät edellisen vaiheen. Urakoitsija puolestaan hyväksyttää oman osansa seuraavan vaiheen toteuttajalla ja työn tilaajalla. Tilaajan kannalta työn teettäminen urakoitsijalla on usein tarkoituksenmukaista, koska se voidaan teettää myös normaalin virka-ajan ulkopuolella. Harvoin tarvittavista ko- 
neista ja laitteista aiheutuu lisäksi suuri pääomakustannus yksittäistä työsuoritusta kohti, ja urakoitsijan työvoima on tottunut käyttämään myös tilaajan töissä harvoin tarvittavia koneista ja laitteita ammattitaitoisesti. Tuntiveloitusperusteisissa töissä hintaan vaikuttavat työkoneen ominaisuudet lisävarusteineen, työntekijän ammattitaito, kokemus ja työsaavutus sekä mahdolliset päivystyslisät ja mahdolliset tilaajasta, yleisöstä tai alueella olevista vierasesineistä aiheutuvat työsuorituksen keskeytymiset. Epävarmuustekijöistä huolimatta urakoitsijan on pystyttävä antamaan kilpailukykyinen mutta ei alihintainen tarjous. Liian kallis tarjous ei menesty ja alihintainen ei täytä menestyvän liiketoiminnan tunnusmerkkejä.

Viherympäristöurakoinnin aloittamista harkitsevan viljelijän tulee ottaa myös urakointikäytön vaatimukset huomioon uusien työkoneiden hankinnassa. Tietyt koneiden lisäominaisuudet saattavat avata merkittäviä urakointitilaisuuksia lisäämättä merkittävästi koneen hankintahintaa. Lisääntynyt käyttö puolestaan laskee työtunnille laskettavaa pääkustannusta. Varsinkin vierasesineistä vapaa viheralueilta poistettu biomassa voidaan hyödyntää maatilalla eri tarkoituksiin.

\section{Työmenekki ja kustannukset viherurakoinnissa}

Viherympäristöurakoinnissa saattaa viljelijälle tulla yllätyksiä työnmenekistä. Esimerkiksi pientareiden niittoa hidastavat liikennemerkit, sähkö- ja valopylväät, linja-autopysäkkien katokset ja mahdollinen liikenne. Lisäksi yleisillä alueilla voi olla erilaista hylkytavaraa, joka hidastaa työtä ja aiheuttaa vaaratilanteita sinkoilevien esineiden muodossa. Esimerkiksi pientareen niittoon meni vaikeahkossa kohteessa 13,8 minuuttia kun helpossa kohteessa meni vain 7,3 minuuttia 1050 metriä kohti (Partanen ym. 2004, Pentti 2004). Tähän pitäisi lisätä 8-10 \%:n häiriölisä. Toisaalta hyvin perustetulla maisemapellolla tai -niityllä niittotyö ei ero merkittävästi tavallisesta heinän tai kesannon niitosta. Esimerkiksi 15 m kertaa 500 metrisen maisemapellon niiton kustannukset niittotähteet keräten ilman siirtymisiä ja korjatun biomassan siirtoa pois lohkolta oli menetelmästä riippuen noin 120 - $160 € \mathrm{ha}^{-1}$. (Palva 2003, Pentti 2003, Partanen ym. 2004). Lohkot saattavat kuitenkin olla pieniä ja hajallaan keskustassa, jolloin siirtymisiin menee yllättävän paljon aikaa. Huomioon on otettava myös se, että koneita ei noin vain voi jättää työmaalle yöksi tai pidemmäksi ajaksi, kuten maataloudessa usein tehdään.

\section{Viherympäristöurakointiin sopivat maatilojen koneet}

Kirjekyselyiden ja haastatteluiden perusteella koneiden saattavuus ei ollut kunnille mikään erityisen ongelma. Varsinaiseen viljelyyn tarkoitettuja koneita kunnilla ei yleensä kuitenkaan ole, mikä lisääkin viljelijöiden kilpailukykyä näiden töiden urakoinnissa. Kuntien vihertoimesta vastaavat eivät välttämättä tunne maatalouskoneiden soveltuvuutta vihertöihin, mikä vähentää niiden käyttöön kohdistuvaa kysyntää. Yrittäjät olivat myös tarvittaessa valmiita investoimaan uusiin koneisiin. Kaikki koneet eivät kuitenkaan sarjavalmisteisena välttämättä sovellu vihertöihin, vaan niitä myös rakennetaan tarpeen mukaan itse.

Kasvinviljelytilojen kalusto, joka on tarkoitettu lähinnä viljanviljelyyn, sisältäen maanmuokkauskalustoa, kuten auroja äkeitä ja jyrsimiä, ja kylvökalustoa ovat käyttökelpoisia viheralueiden peruskunnostuksessa ja kasvuston perustamisessa. Joillakin niistä on kesantomurskain, joka soveltuu viheralueiden niittoon.

Kotieläintiloilla on viljanviljelyyn sopivan kaluston lisäksi käytössään enemmän viheralueiden hoitoon sopivia nurmiviljelykoneita. Keskeisin puute maatiloilla on kuitenkin nivellettyyn puomiin kiinnitetty niittolaite, jota käytetään leveiden luiskien ensimmäistä seuraavien laistojen niittoon. Karjatiloilla on kuitenkin vähemmän aikaa tilan ulkopuolisin töihin. Näiden tilojen koneiden käyttö viherurakointiin tulee mahdolliseksi lähinnä karjanpidon lopettamisen jälkeen.

Tavanomaiset maatalouden maanmuokkaus-, niitto-, korjuu- ja kuljetusvälineet soveltuvat yleensä hyvin tai melko hyvin maaseutumaisten alueiden hoitoon, mutta joidenkin koneiden kestävyys, raskaus tai suuri koko saattaa haitata joissakin töissä. Maatalouskoneita voi joutua vahvistamaan kestämään viheralueiden epätasaisuuksia, ajoesteitä ja vierasesineitä. Alueiden peruskunnostus pienentää hoitotöiden työnmenekin lisäksi koneiden kestävyydelle asetettavia vaatimuksia. Tilaajat saattavat vaatia maatalouskoneista kevyemmän kaluston käyttöä (Virkkunen 2004), jota yrittäjällä pitää olla tavallisten maatalouskoneiden lisäksi. Ongelmaa voi lievittää esimerkiksi paripyörien käytöllä. Myös vanhemmat koneet saattavat olla sopivan kokoisia niittotöihin.

Viljelyyn ja niittoon soveltuvien koneiden lisäksi tiloilla on runsaasti erilaista muihin töihin soveltuvaa kalustoa, joiden käyttö tulee ajankohtaiseksi sitä mukaa, kun viljelijät osallistua enemmän myös näiden töiden urakointiin. 


\section{Johtopäätökset}

Määrärahojen puute on kunnilla ja seurakunnilla suurin este maaseutumaisten alueiden hoidon lisäämiseen. Vasta sen jälkeen on pula vihertoimesta vastaavien ja suorittavan portaan ajasta. Määrärahat tuskin ovat lisääntymässä, vaikka haluja hoidon lisäämiseen on. Niinpä hoidettavien alueiden lisääntyminen on mahdollista vain siirtämällä alueita puistomaisen hoidon piiristä maaseutumaisen hoidon piiriin. Tämä vastaisi myös kuntalaisten toiveita, mutta ilmeisesti vihertoimesta vastaavat jossain määrin epäröivät siirtymistä käyttämään enemmän maaseutumaista hoitoa. Tässä voisi auttaa tarkemmat selvitykset kuntalaisten toiveista ympäristönsä suhteen. Maaseutumaisen hoidon lisääntymisestä hyötyisi myös viljelijät, koska heille sopivien hoitokohteiden määrä ja osuus kasvaisi. Tähän pitäisi myös kunnilla olla intressejä, koska ne kokivat pulaa pystyvistä urakoitsijoista. Urakoitsijoille asetettavat vaatimukset ja viljelijöiden ammattitaito kohtaisivat tällöin useammin molempien osapuolten eduksi. Merkittävimmin viljelijäurakoitsijoiden urakointimahdollisuudet kuntien viherympäristönhoitotöissä lisääntyisivät kuitenkin lisäämällä heidän valmiuksiaan muissa kuin varsinaisissa viljelytöissä.

Varsinaisissa viljelytehtävissä viljelijöiden käytön osuus viherympäristönhoitotöissä ei edes juuri voisi enää nousta lukuun ottamatta niittymäisesti hoidettavien alueiden eli maisemaniittyjen hoitoa samantapaisena toimintamuotona kuin maisemapeltojenkin hoidossa tai ottamatta pusikoituvia peltoja uudelleen viljelyyn maisemapeltoina. Viljelijät osallistuvat viherympäristön hoitoon vuokraamalla kunnilta peltoa tuottaen maisemapeltoa vastaavaa ympäristöelementtiä. Pelkkä niittyjen ja peltojen niitto ei vaadi yhtä suurta ammattitaitoa viljelijänä ja monipuolista viljelyyn sopivaa kalustoa kuin maisemapeltojen viljely, joten muiden yrittäjien kilpailukyky suhteessa viljelijöihin on suurempi kuin varsinaisissa viljelytöissä. Viljelytöitä lukuun ottamatta viherympäristötöissä korostuukin kyky kilpailla muiden urakoitsijoiden kanssa samoista lähtökohdista, missä hallitsevaksi nousee nimenomaisesti kyky toimia urakoitsijana. Kunnat ovat halukkaita lisäämään viljelijöiden käyttöä viherympäristönhoitotöissä, mutta sitä ilmeisesti rajoittaa sopivien tehtävien ja määrärahojen puute. Kunnilla ei näyttänyt olevan mitään viljelijätaustaisia urakoitsijoita vastaan, mutta he joutuivat varsin kovaan sarjaan muiden urakoitsijoiden kanssa varsinaisia viljelytöitä lukuun ottamatta. Seurakunnat sen sijaan katsoivat jo käyttävänsä viljelijöitä tarkoituksenmukaisessa laajuudessa ja käyttivät heitä nimenomaisesti viljelytöissä. Seurakuntien näkemykset olivat hyvin selkeät, ja niiden määrärahojen niukkuus kuntienkin vastaavaa suurempi.

Maaseutuyrittäjät pitävät kuntia samanlaisen sopimuskumppanina kuin muitakin. Heille saattaa olla vaikeaa arvioida maataloustöitä muistuttavien töiden suurempi työnmenekki taajamaoloissa. Kunnilta toimiminen viljelijäurakoitsijoiden kanssa saattaa vaatia tavanomaista enemmän panostusta töiden ohjeistukseen varsinkin alkuvaiheessa. Selkeät pelisäännöt ovat eduksi kuitenkin kaikkien kanssa toimimisessa. Kummatkin osapuolet haluavat palautetta toisiltaan. Resurssien ollessa niukat kunnat pyrkivät suurempiin kokonaisuuksiin, kuten hoitosopimuksiin, joihin viljelijäyrittäjät pääsevät kiinni lähinnä erilaisten yhteenliittymien kautta.

Maatalouskoneiden soveltuvuus vihertöihin ei ole merkittävä ongelma, mutta ei välttämättä kuntien vihertoimesta vastaavien tiedossa. Jotkin muutokset ja vahvistukset ovat tarpeen.

\section{Kirjallisuus}

Eskola, R. 2003. Viheralueiden rakentaminen ja valvonta. Viherympäristöliitto ry. Julkaisu 27.

Klemola, E., Pihamaa, P \& Heikkilä, A.-M. 2000. Laajentavan lypsykarjatilan tuotannon ja työkäytön suunnittelu. Työtehoseuran julkaisuja 375: $1-88$.

Palva, R. 2003. Suojavyöhykkeiden hoito. Työtehoseuran maataloustiedote 555: 1 - 6 .

Partanen, H, Seppo, P. Kapuinen, P. \& Nysand, M. 2004. Maaseutuyrittäjien mahdollisuudet viherympäristötöissä. Työtehoseuran raportteja ja oppaita 14: 1 - 70.

Pentti, S. 2003. Konetyön kustannukset ja tilastolliset urakkahinnat. Työtehoseuran maataloustiedote 558: $1-12$.

Pentti, S. 2004. Maaseutuyrittäjät ja ympäristöurakointi. Työtehoseuran maataloustiedote 573: 1 - 4 . Viherympäristöliitto. 2000. Viheralueiden hoitoluokitus. Viherympäristöliitto ry. Julkaisuja 16: 1 48.

Virkkunen, M. 2004. Maaseutuyrittäjälle kaupunkimaisema on mahdollisuus. Farmari 2004. Maaseudun tulevaisuus (2.8.2004)

YM. 2003. Valtakunnallisten alueidenkäyttötavoitteiden soveltaminen kaavoituksessa. Maankäyttö- ja rakennuslaki 2000. Ympäristöministeriö. Opas 9: 1 - 52. 